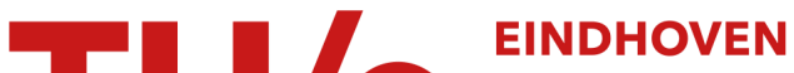 UNIVERSITY OF TECHNOLOGY
}

\section{A note on the shape of the shear-plane in orthogonal cutting}

Citation for published version (APA):

Mot, E., \& Veenstra, P. C. (1967). A note on the shape of the shear-plane in orthogonal cutting. International journal of machine tool design and research, 7(2), 169-173. https://doi.org/10.1016/0020-7357(67)90031-5

DOI:

10.1016/0020-7357(67)90031-5

Document status and date:

Published: 01/01/1967

\section{Document Version:}

Publisher's PDF, also known as Version of Record (includes final page, issue and volume numbers)

\section{Please check the document version of this publication:}

- A submitted manuscript is the version of the article upon submission and before peer-review. There can be important differences between the submitted version and the official published version of record. People interested in the research are advised to contact the author for the final version of the publication, or visit the $\mathrm{DOI}$ to the publisher's website.

- The final author version and the galley proof are versions of the publication after peer review.

- The final published version features the final layout of the paper including the volume, issue and page numbers.

Link to publication

\section{General rights}

Copyright and moral rights for the publications made accessible in the public portal are retained by the authors and/or other copyright owners and it is a condition of accessing publications that users recognise and abide by the legal requirements associated with these rights.

- Users may download and print one copy of any publication from the public portal for the purpose of private study or research.

- You may not further distribute the material or use it for any profit-making activity or commercial gain

- You may freely distribute the URL identifying the publication in the public portal.

If the publication is distributed under the terms of Article 25fa of the Dutch Copyright Act, indicated by the "Taverne" license above, please follow below link for the End User Agreement:

www.tue.nl/taverne

Take down policy

If you believe that this document breaches copyright please contact us at:

openaccess@tue.nl

providing details and we will investigate your claim. 


\title{
A NOTE ON THE SHAPE OF THE SHEAR-PLANE IN ORTHOGONAL CUTTING
}

\author{
E. Mot* and P. C. VeEnstra $†$
}

(Received 23 November 1966)

\begin{abstract}
In the classical model of orthogonal cutting, as developed by M. E. Merchant, the shear-plane is represented by a flat plane. Microphotographs have shown that this assumption can be considered a reasonable approximation of reality.

However, it can be proved that this model is inconsistent with the fact that the chip curls during the cutting-process.

In this paper an effort has been made to produce an extension of the Merchant model, assuming a curved chip and, consequently, a curved shear-plane.
\end{abstract}

\section{THEORY}

The classical model

To DESCRIBE this model the following quantities are defined
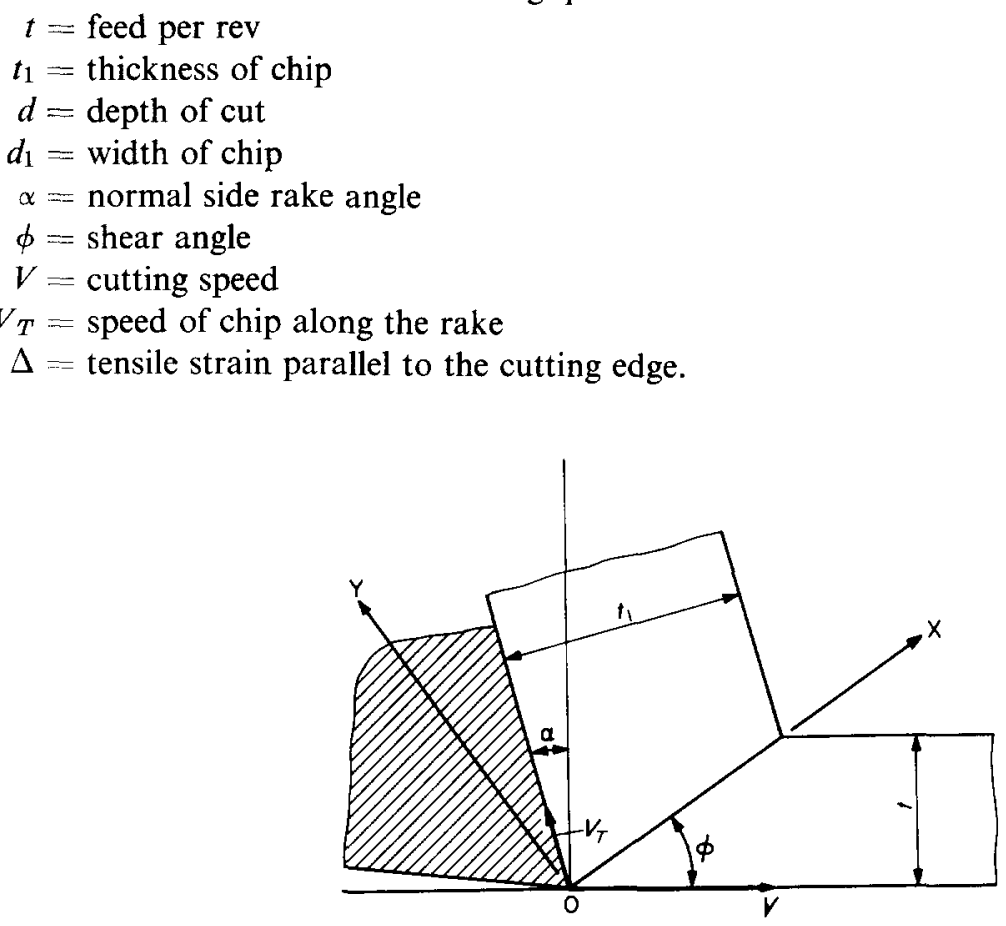

FiG. 1. The classical model of orthogonal cutting.

\footnotetext{
* Graduate student, Department of Production Engineering, Technological University Eindhoven, Netherlands.

$\dagger$ Professor of Production Engineering, Technological University Eindhoven, Netherlands.
} 
The tensile strain in the direction parallel to the cutting edge $(\Delta)$ follows from

$$
d_{1}=d(1+\Delta) .
$$

Further, from geometrical considerations, it can be seen (Fig. 1) that

$$
t_{1}=\frac{t \cos (\phi-\alpha)}{\sin \phi} .
$$

The relation between $V$ and $V_{T}$ follows from the continuity equation for the material which passes along the shear-plane

$$
t . d . V=t_{1} \cdot d_{1} . V_{T} .
$$

Using (1) and (2) we find from (3)

$$
V_{T}=\frac{V \sin \phi}{(1+\Delta) \cos (\phi-\alpha)} .
$$

Thus we find $V_{T}$ as a function of $\phi$.

When $V_{T}$ does not vary in the X-direction, the chip will come off straight. We know, however, that this is not correct: the chip actually comes off in a curved shape. This is only possible when a speed distribution $V_{T}=V_{T}(x)$ exists, thus, using (4): $V_{T}=V_{T}(\phi)$, leading to $\phi=\phi(x)$. This implies a curved shear-plane.

\section{The curved shear-plane model}

We will assume a chip contact-length of $l_{c}$. The velocity-field is chosen in such a way that all along any line $\mathrm{ABC}$ which is pseudo-parallel to the chip-boundary, the speed of the chip is constant. We shall also assume that the curved part of the chip is a rigid body. If the outside radius of the chip is $R$, we find the pole $\mathrm{M}$ according to Fig. 2 . The relation between $V_{T}(0)$ and $\mathbf{V}_{T}(x)$ is then given by

$$
V_{T}(x)=V_{T}(0) \frac{R-x \cos (\phi-\alpha)}{R} .
$$

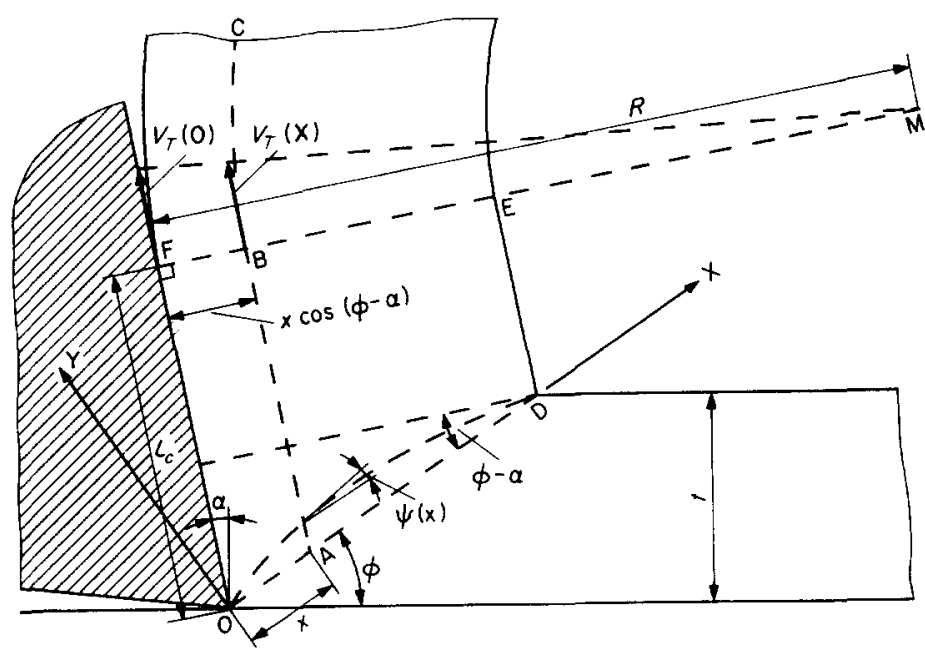

FIG. 2. The curved shear-plane model. 
The assumed speed distribution implies that the part ODEF cannot be entirely rigid. Actually, from experiments it is known that secondary plastic deformation does take place in that region, especially near the rake plane of the tool. To describe the shape of the shear plane, we superimpose a variable angle $\psi=\psi(x)$ on the constant angle $\phi$. Then, localisation of (4) gives

$$
V_{T}(x)=\frac{V \cdot \sin [\phi+\psi(x)]}{(1+\Delta) \cos [\phi-\alpha+\psi(x)]} .
$$

Substituting $x=0$ in (6) we obtain

$$
V_{T}(0)=\frac{V \sin [\phi+\psi(0)]}{(1+\Delta) \cos [\phi-\alpha+\psi(0)]}
$$

(6) and (7) in (5) gives

$$
\frac{\sin [\phi+\psi(x)]}{\cos [\phi-\alpha+\psi(x)]}=\frac{R-x \cos (\phi-\alpha)}{R} \cdot \frac{\sin [\phi+\psi(0)]}{\cos [\phi-\alpha+\psi(0)]} .
$$

The angle $\psi$ is small. Thus we approximate

$$
\begin{aligned}
& \cos \psi \approx 1 \\
& \sin \psi \approx \psi \approx \tan \psi=\frac{d y}{d x}=y^{\prime} .
\end{aligned}
$$

From (8) we can now easily derive

$\frac{\sin \phi+y^{\prime} \cos \phi}{\cos (\phi-\alpha)-y^{\prime} \sin (\phi-\alpha)}=\frac{R-x \cos (\phi-\alpha)}{R} \cdot \frac{\sin \phi+y^{\prime}(0) \cos \phi}{\cos (\phi-\alpha)-y^{\prime}(0) \sin (\phi-\alpha)}$

or

in which

$$
y^{\prime}=\frac{A x+B}{C x+D}
$$

$$
\begin{aligned}
& A=-\cos ^{2}(\phi-\alpha)\left\{\sin \phi+y^{\prime}(0) \cos \phi\right\} \\
& B=y^{\prime}(0) R \cos \alpha \\
& C=-\cos (\phi-\alpha) \sin (\phi-\alpha)\left\{\sin \phi+y^{\prime}(0) \cos \phi\right\} \\
& D=R \cos \alpha .
\end{aligned}
$$

Integration of (11) gives

$$
y=\frac{A}{C} \cdot x+\frac{B C-A D}{C^{2}} \ln (C x+D)+C_{1}
$$

with boundary conditions

$$
y(0)=0 \quad \text { and } \quad y\left(\frac{t}{\sin \phi}\right)=0 .
$$

By substitution of (13a) in (13) we find two equations, which enable us to solve the unknown quantities $C_{1}$ and $y^{\prime}(0)$. Then the shape of the shear-plane is known. 
We will illustrate this consideration with a numerical example

$$
\begin{aligned}
\phi & =30^{\circ} \\
\alpha & =10^{\circ} \\
R & =5 \mathrm{~mm} \\
t & =0.6 \mathrm{~mm} / \mathrm{rev} .
\end{aligned}
$$

From these assumed data, which may be obtained from experiments, we calculate according to (12)

$$
\begin{aligned}
& A=-0.4415-0.7647 y^{\prime}(0) \\
& B=4.9240 y^{\prime}(0) \\
& C=-0 \cdot 1607-0.2783 y^{\prime}(0) \\
& D=4.9240 .
\end{aligned}
$$

Substitution of (15) in (13) gives

$$
y=2 \cdot 7475 x-\frac{4 \cdot 9240 y^{\prime}(0)-13 \cdot 5287}{0 \cdot 2783 y^{\prime}(0)+0 \cdot 1609} \ln \left[\left\{-0 \cdot 1607-0 \cdot 2783 y^{\prime}(0)\right\} x+4 \cdot 9240\right]+C_{1} \text {. }
$$

The boundary conditions

$$
y(0)=0 ; \quad y(1 \cdot 200)==0
$$

can now be substituted in (16). Then, we find

$$
\begin{aligned}
& 0=\frac{4 \cdot 9240 y^{\prime}(0)-13 \cdot 5287}{0 \cdot 2783 y^{\prime}(0)+0 \cdot 1607} \ln 4 \cdot 9240+C_{1} \\
& 0=3.297-\frac{4 \cdot 9240 y^{\prime}(0)-13 \cdot 5287}{0.2783 y^{\prime}(0)+0 \cdot 1607} \ln \left\{4 \cdot 7312-0 \cdot 3340 y^{\prime}(0)\right\}+C_{1} .
\end{aligned}
$$

Elimination of $C_{1}$ from (17a) and (17b) gives

$$
\ln \left\{4 \cdot 731-0 \cdot 3340 y^{\prime}(0)\right\}-\frac{8 \cdot 7669 y^{\prime}(0)-21 \cdot 0363}{4 \cdot 9240 y^{\prime}(0)-13 \cdot 5287}=0 \text {. }
$$

(18) can be solved by successive approximation according to Newton. Then (17a) gives $C_{1}$. We find

$$
\begin{aligned}
y^{\prime}(0) & =0.0576 \\
C_{1} & =-119 \cdot 4901
\end{aligned}
$$

For the equation of the shear-plane, we find in this case, by substitution of (19) in (16)

$$
y=2 \cdot 7475 x-119 \cdot 4901+74.9581 \ln (-0.1767 x+4.9240) .
$$

From (11) we find

$$
\psi=y^{\prime}=\frac{-0.4856 x+0.2836}{-0.1767 x+4.9240} .
$$


Table 1 gives some local values of the actual shear angle.

TABLE 1

\begin{tabular}{lccl}
\hline $\begin{array}{c}\mathrm{x} \\
(\mathrm{mm})\end{array}$ & $\begin{array}{c}\psi \\
(\mathrm{rad})\end{array}$ & $\begin{array}{c}\psi \\
\text { (degrees) }\end{array}$ & $\begin{array}{c}\text { Shear } \\
\text { angle }\end{array}$ \\
\hline 0 & 0.0576 & $3^{\circ} 19^{\prime}$ & $33^{\circ} 19^{\prime}$ \\
$0 \cdot 2$ & 0.0385 & $2^{\circ} 13^{\prime}$ & $32^{\circ} 13^{\prime}$ \\
0.4 & 0.0184 & $1^{\circ} 4^{\prime}$ & $31^{\circ} 4^{\prime}$ \\
$0 \cdot 6$ & -0.0014 & $-0^{\circ} 5^{\prime}$ & $29^{\circ} 55^{\prime}$ \\
$0 \cdot 8$ & -0.0215 & $-1^{\circ} 14^{\prime}$ & $28^{\circ} 46^{\prime}$ \\
$1 \cdot 0$ & -0.0415 & $-2^{\circ} 22^{\prime}$ & $27^{\circ} 38^{\prime}$ \\
1.2 & -0.0622 & $-3^{\circ} 34^{\prime}$ & $26^{\circ} 26^{\prime}$ \\
\hline
\end{tabular}

Remark. It seems only correct to mention a limitation of this model; we have, indeed, neglected the fact that a temperature distribution $T=T(x)$ exists, which will influence the value of $R$ as long as the chip is in touch with the tool. After the chip has come off, we may measure a different outside radius, since the temperature distribution then has disappeared.

\section{CONCLUSION AND PROSPECTS}

We have shown that from experimental data the local value of the shear angle can be computed. Its variation may be in the order of \pm 10 per cent. In the existing literature on orthogonal cutting, based on the Merchant model, in many cases average stresses are calculated, dependent on the value of the shear angle.

With the help of this theory, these calculated values may be localised, thus giving a stress distribution. In practice this means that the measurement of the radius $R$ in addition to the usual quantities measured, enables us to find a stress distribution on the shear plane from a number of experiments which each individually provide us with values of average stresses. The solution will, however, be only kinematically admissible. If $\sigma_{y}(x)$ is the normal stress distribution on the shear-plane and $P_{T}$ the normal pressure on the tool, we may find the working point of $P_{T}$ using the equilibrium of moment of the chip round $\mathrm{O}$

$$
\int_{0}^{t / \sin \phi} d \cdot \sigma_{y}(x) \cdot x d x=P_{T} \cdot b
$$

where $b$ is the distance between $\mathrm{O}$ and the working point of $P_{T}$. In (22) we may substitute either $d=$ constant or $d=d(x)$. 